\title{
Hamlet's Father: Hauntology and the Roots of the Modern Self
}

\author{
Lukas Szrot
}

In his 1949 work Hamlet's Ghost, Richard Flatter wrote of the ghost of Hamlet's father that the play ultimately belongs to him, to the ghost. Modernity, like the play, belongs to its ghosts, to its dead fathers haunting their wayward sons, the metaphysical specters it imperfectly endeavors to exorcise. Critical theory has often focused on the possibility, and the contours, of a utopia populated by liberatory spirit and liberated persons. Less well explored, however, are the implications for ethics, nature, and the transmission of culture at a metaphorical echelon-those ostensibly "pre-modern" ideas which the broader project of Enlightenment liberalism never fully leaves behind. Drawing upon thinkers as diverse as Marcuse, Derrida, Weber, and Nietzsche, I read Shakespeare's Hamlet, particularly the interaction between the ghost of the father and his vacillating son, as a metaphor for the failure to achieve a soughtafter post-metaphysical world, and the ominous potential that inheres in the resulting ambivalence. The implications of these philosophical and sociohistorical developments are centered around the social-psychological emergence of a modern self, at once alienated from history and nature, but perhaps able to re-imagine selfhood from "outside the iron cage."

\section{Hamlet's Father: Hauntology and the Roots of the Modern Self}

In his 1949 work Hamlet's Ghost, Richard Flatter (1949) wrote of the ghost of Hamlet's father: "Can we ever say that he ceases to be there? He is not there in person, but in principle, so to speak; not visible all the time, but all the time perceptible - by the task he has laid on his son's shoulders... The motive of the play is the Ghost's; and in this sense, it may be said, it is his play" (6). "The Ghost, though not the protagonist, is the real motive power of the play. For long stretches, he keeps behind (or under) the stage. Yet all the time- 'seeing, unseen'-he watches the progress of his case and is prepared to intervene if need be" (60). Like the play, perhaps "modernity" belongs in many ways to its spirits, to its dead fathers haunting their wayward sons, to the past it only pretends to leave behind, to the metaphysical specters it imperfectly endeavors to exorcise. This work takes as its starting-point Levinas' invitation to examine Hamlet as a means by which to engage the ethical—and political—demands involved in a confrontation with the other, with the past, with destiny, and with death (Griffiths 2005:163; see also Levinas 1985, 1989). ${ }^{1}$

This confrontation with modernity's ostensible "other" takes place amid a transition from a medieval human selfhood and agency still inextricably bound to social station and family relations and a post-meaning man for whom, to quote Agger: "The loss of meaning is occasioned by a peculiarly ahistorical view of the world, which is flattened into an eternal present. We don't know who we are, or what formed us" (Agger 2002:3). To re-examine post-modernity retrospectively is to revisit this ahistorical "flattening," which had its roots in the modern. Central to the work at hand is the transition of Hamlet's self over the course of the play in relation to the oath he takes to the ghost of his father, the slain king, and how this transition is a microcosm of the rise of a new self in the context of a new constellation of political, ethical, and social relations. 


\section{Trafficking in Ghosts: Moral Realism and Scientific Naturalism}

The "other" that appears as death, as a ghost, is neither alive nor dead, but somewhere in-between, a vestige of a world before history allegedly ended and in so doing breathed new life into the prefix post-. To think on death while living is to inhabit a haunted realm, of cogitation in the face of the singularly unpleasant, and (perhaps eternal) unrest. Derrida (1994) opened Specters of Marx by speaking of learning "to live with ghosts, whether revolutionary or not, living otherwise, living better... a politics of memory, of inheritance, and of generations" (xviii). I will speak of religion, and of rationality, as aspects of such a politics, defined in part by our dynamic relationship to the term nature. I speak not necessarily as a naturalist, whatever that may ultimately mean-it can indeed be demonstrated that a narrow philosophical naturalism, the view that "science exhausts rationality" is "a self-stultifying error" (see Matteo 1996; Putnam 1995; Szrot 2015). ${ }^{3}$ The logical positivist exorcisms Marcuse (1964) railed against as onedimensional thought in the form of "confusing metaphysical notions- 'ghosts' of a less mature and less scientific past which still haunt the mind although they neither designate nor explain" (170) have themselves become ghosts of Anglophone philosophy. Everywhere the practicing scientist, philosopher, or educator insists on a distinction between the noumenal and phenomenal (see Lough 2006), between methodological and metaphysical naturalism (see Alters 2005), between science and religion as non-overlapping magisteria (see Gould 1999), the ghost of a disciplined naturalism hangs heavy. And naturalists, whatever else they do, do not traffic in ghosts.

The term hauntology emerges from the work of Derrida, a collapse of the ontological into the teleological and eschatological (1994:63). Put plainly, given a current state of affairs into which we may be thrust, however blissful or intolerable (it is the latter that creates the story arc of Hamlet), for what can we hope, and toward what are we obligated? Such questions lie in part beyond a naturalist conception of rationality. The ghost's exhortation to the young prince at the end of the first act of the play draws attention to the possibility of a broader conception of reality:

And therefore as a stranger give it welcome.

There are more things in heaven and earth, Horatio,

Than are dreamt of in our philosophy (1.5. 862-864).

And in the final moments of the first Act, Hamlet curses his fate:

The time is out of joint. Oh, cursèd spite,

That ever I was born to set it right (1.5 885-886)!

Hamlet's "terrible purpose" is established: vengeance on behalf of his murdered father, the restoration of temporal order, and a continuation of history. The time is out of joint - the present is metaphysically corrupted, unbearable. The ghost becomes real — a father, a figure from both a temporal and a metaphysical past—and in so doing sets into motion the sequence of events that dominate the narrative arc. The ghost sees while remaining unseen, a power granted entities populating the purgatory between life and death. Hamlet inherits a Herculean burden-he does not carry it well, say some commentators, and has been accused of cowardice in the face of righting a grievous injustice (see, for example, Flatter 1949:83-90). There is much debate as to whether Prince Hamlet failed to act on his oath to the ghost of his father out of cowardice. While I do not directly take a position on this particular issue, I do note for this analysis that extended deliberation before action is in many ways seen as the hallmark of "rational man," and a subset of this type, "scientific man," a creature ostensibly ruled by intellect and reason rather than passions and engaged in systematic study of any phenomenon, often before, and sometimes in place of, acting. The oath is the young prince's initial response-protracted cogitation, his second; Hamlet must test the ghost's pronouncements systematically, scientifically, in the course of this work. There is something thoroughly modern — at once methodical and methodological — in his approach to validating the ghost's claims. To test the ghost's claims, the young prince arranges for the showing of a play he rechristens The Mouse-Trap to determine his Uncle Claudius' guilt in the murder, and in the closet scene, Hamlet confronts his mother, which the ghost clearly forbade as part and parcel to the oath:

Taint not thy mind, nor let thy soul contrive

Against thy mother aught; leave her to heaven

And to those thorns that in her bosom lodge

To prick and sting her. Fare thee well at once (1.5 770-773). 
I am of two minds on the significance of this. Perhaps Hamlet's skepticism toward the ghost perhaps betrays a timidity, a desire to escape taking a principled stand (see Weber 1946:94-5) as is necessary for the commitment to an ethical or a political course of action. Of course, it is also the vision of rational prudence, of one unwilling to act until the preponderance of evidence is on one's side. This tension between episteme and praxis-between how we know what we know, and what we should then do-haunts us moderns still, particularly when we academicians seek to engage publics, abandon jargon or utilize practical reason (see Szrot 2019). Hamlet's failure, then, may be rooted in lack of nerve, but may also arise from an effort to create - to exaggerate - the disjuncture between knowledge and politics. More can always be known, scientifically, but how much must be known before we act?

\section{| Hamlet as Morality Play: Agency and Providence, Madness and Sanity, Life and Death}

The ghost chastises young Hamlet for his delays, and for this confrontation. Hamlet is in another sense locked into a destiny, a providential calling. His is akin to Weber's (2011) reading of the famous Puritan literary work Pilgrim's Progress: the ghost expects Hamlet to suspend doubt: he swore to reveal the ghost's missive to none, and to dutifully realize his destiny (121). This begins the tension between the Hamlet of the middle of the play, who is a rational investigator of the veracity of the ghost's claims, and the Hamlet of the end, who displays a belief in divine Providence and an acceptance of fate. There is an implicit reference to something like a morality play here, in which the solitary believer must strive, oblivious to the world, toward salvation. Hamlet's terrible purpose drives him forward toward death at the end of a poisoned blade - a death preceded by his mother and his treacherous uncle. When Hamlet delays, lives are lost. He is exiled and returns. In the end, the young prince accepts his fate, a converted and providential Stoic — a fate that will include his death. Young Hamlet lives in the twilight zone between life and death throughout the play_-in Act 1, scene 2, predating his father's arrival, Hamlet cries out in despair:

Oh, that this too solid flesh would melt,

Thaw, and resolve itself into a dew!

Or that the Everlasting had not fixed

His canon 'gainst self-slaughter. O God, O God!

How weary, stale, flat, and unprofitable

Seems to me all the uses of this world (1.2 313-318)!

Perhaps inadvertently, the ghost brings to fruition the death-wish of a man locked between madness and sanity. Hamlet ties his fate to that of his father's ghost; the future unfolds in accordance with the hauntology of a dead king, and unravels when Hamlet departs from his oath. Fatalism dominates Hamlet's mood near the end of the play, giving reason to see in Hamlet a bridge_or a chasm_-between a "pre-modern" self, locked to the will of an inscrutable Deity and naturalized social order, and a modern, worldly "humanistic" self, seeking to control nature and destiny through observation and experiment. Catherine Belsey (1985) calls Hamlet "the most discontinuous of Shakespeare's heroes," citing medieval mystery plays such as Everyman and The Castle of Perseverance to make the argument that Hamlet represents a character straddling the medieval and modern conceptions of individual agency and the self (41; see also Griffiths 2005:113). Hamlet's role in the play is Providential; he is beholden to an anthropomorphized Godhead, as an avatar of what Weber (2011) called The Protestant Ethic, a torchbearer from the medieval to the modern, from the feudal to the capitalist. The Hamlet of Act 5 speaks accordingly in a recognizably ascetic Calvinist manner:

There's a divinity that shapes our ends,

Rough-hew them how you will. (5.2 10-11)

And to Horatio, when Hamlet presumably speaks of the imminence of his own death:

Horatio: If your mind dislike anything, obey. I will not forestall their repair hither, and say you are not fit.

Hamlet responds: Not a whit-we defy augury! There's a special providence in the fall of a sparrow. If it be now, 'tis not to come: if it be not to come, it will be now: if it be not now, yet it will come. The readiness is all. Since no man has ought of what he leaves-what is't to leave betimes? (5.2 217-224) 
In Act 1, we first witness Hamlet's despair and his oath to his father. Between the end of Act 1 and the second scene of Act 5, Hamlet has changed in fundamental ways. A young prince caught between haunting, rationality, and finally Providence comes to bridge different worlds and their value-spheres: the ethical-political and the scientificrational, on one hand, which neither collapse into one another nor are entirely separate, and the Providential and the empirical. Scholars from Nietzsche and Weber to Merton argued that the latter has roots in the former (see Evans and Evans 2008:94-5; Merton 1970; Nietzsche 1967:148-49, fn5; Weber 1946:134-44). Like Hamlet mid-play, we who cling to modernity are prone to the belief that we have broken the spells of the ascetic priests of the past ${ }^{7}$ where $^{-}$ we have only pretended to. Modernity is steeped in sociological ambivalence (see Merton 1976:4-12); as narrative it retains a Calvinistic flavor in its quasi-teleological predictions and reaches eschatological crescendo in the 1990s as scholars such as Francis Fukuyama (1992) proclaimed that the fall of the Soviet Union enthroned liberal democracy and technological society as "the end of history." The social psychology of the modern self wends its way from Shakespearean drama through the work of Nietzsche and Weber, shedding light on some of the tensions that inhere in the present-by whatever we choose to call it - the aforementioned site of historical amnesia and historical flattening. The ideas that gave rise to totalitarianism, and to fascism, among others, still haunt us-one only need to spend a few minutes on social media to find political dialogue across numerous liberal democracies has taken on a renewed divisiveness, demagoguery, and demonology in recent years. Hauntology holds forth both liberating potential and terrible promise.

The "Spirit of Capitalism," as Weber famously remarked, was in its roots Protestant, a "this-worldly asceticism" which focused attention on activity in this world coupled with, and giving rise to, a staunch individualism (2011:120). The modern self that arose from, and gave rise to, liberal democracy and technological society stands perched on a decidedly theological base. That individualistic theology, that radical alterity of divinity, the insuperable gulf between human beings and divine will, has manifested itself in decidedly divergent ways. It is implicated in continued racial and ethnic tensions in the Western world, in reducing racial-ethnic disparity in income and social standing to individual sin rather than historical and institutional discrimination in the U.S. (see, for example, Jones 2016), and in new religious and ethnic tensions in Europe (see Modood 2013). On another, its spirit gives rise to a sublime vision of nature as wilderness, as a testament to divine might, foreshadowing certain currents in modern environmentalism (see Stoll 2015). A radical separation of human and divine gave rise to a constellation of diverse phenomena still in the process of unfolding. In short, through the ideas that underpin Hamlet's—and Weber's—historical transition toward the modern individualistic, agentic, empiricist self, one glimpses the ineradicable stamp-the compellingly haunting afterimage_ — of destiny and teleology.

\section{| Rationality and Risk: Hamlet and the Ambivalence of Modern Selves}

Regarding rationality, Nietzsche (1967) notes in The Genealogy of Morals that empirical investigation itself is a holdover of the "ascetic ideal," a worthy labor but also "a means of self-narcosis" (146-47). Hamlet's deliberation and investigation, his efforts to "prove" the veracity of the ghost's conjectures, amount ultimately to a costly and ultimately futile delaying action. So long as uncertainty could be cultivated, Hamlet could find it reasonable to continue to evade his terrible purpose. The epistemic component of an ostensibly post-truth society resonates with this consistent delaying action-casting endless doubt prevents the manifestation of uncomfortable truths and the actions that might logically follow from them. A highly relevant modern example of how investigation can be used to prolong doubt and delay action, and the harrowing consequences that follow therefrom, can be found in ongoing politically- and economically-motivated efforts to challenge threats to public health and the environment, from smoking and pesticide use to climate change (see Oreskes and Conway 2010).

Hamlet's struggles predate the rise of a new self and a new society, in which new ambivalence inheres. The world is more globally interconnected than ever before, and the proliferation of techno-economic innovation has led to sociopolitical dynamics that currently elude our collective grasp. The irony of this is evident to Giddens (2000) — the Enlightenment promise, that "the more we are able to rationally understand the world, and ourselves...the more we can shape history for our own purposes" (19) gave rise to a runaway world, in which "science and technology are inevitably involved [in solving problems]... but they have also contributed to creating [these risks] in the first place" (21). In such a world is it flimsy resolve or laudable prudence to wait, to gather more evidence, to "do more research?" Surely there are cynical reasons for calling for more information before acting; just as surely there is folly 
awaiting those who act without sufficient knowledge. Hamlet's hesitation and despair foreshadow an ostensibly global civilization shot through with risk and ambivalence.

We moderns are endlessly confronted with self-narcosis via this ambivalence-Nietzsche regards will to truth highly in all its ascetic Protestant residue (1967:148-49, fn5), but it is Weber who explicitly and at length distinguishes between the Beruf of the politician and that of the scholar, in that the essence of the former is in "taking a stand" (1946:94-5). ${ }^{8}$ To kill a king is to exercise political will, to take a stand in the Weberian political sense, but to do so at the behest of a ghost is lunacy, barring hard evidence. But how much evidence, and of what kind? The delays surely pain Hamlet throughout the play; he is skeptical, he seeks, but he does not want to believe. To meditate on the character development of Prince Hamlet in relation to the ghost's missive is to examine the dual nature of the modern human in the modern world.

And what a dual nature! In a passage particularly evocative of this new self, arising out of, but not discontinuous with, the old, Hamlet laments:

What a piece of work is a man, how noble in reason, how infinite in faculties, in form and moving, how express and admirable, in action how like an angel, in apprehension how like a god: the beauty of the world, the paragon of animals-and yet, to me, what is this quintessence of dust? Man delights not me-nor woman neither... (2.2.302-309)

Modern man is "the paragon of animals"; man is a "quintessence of dust," is vaguely reminiscent of the flavor of Weber's "last man," the denizens of the iron cage_- "narrow specialists without minds, pleasure-seekers without heart; in its conceit this nothingness imagines it has climbed to a level of humanity never before attained" (2011:178). The earth on which Hamlet envisions these humans, these last men, is "a sterile promontory...but a foul and pestilent congregation of vapours" (2.2. 298-300). The time is out of joint-we are reminded-this is Hamlet's resolve after taking his oath. The monumental task he faces is becoming the person capable of righting what is wrong, and returning natural order as commanded by the unnatural spirit.

\section{Conclusion: Faith and Nature in Modernity}

This new, unnatural order mightily resists re-naturalization. We cannot simply capitulate to the ghost, and in so doing, be seduced by a romanticized past that never really existed, but haunts us in its nonexistence. If the wretched promise of Weber's, and Nietzsche's, last man emerges out of this ethic, the question left to us, finally, is: what is to right these wrongs? Weber, via Lough (2006), offers a hint: “The flight of the 'spirit' of capitalism [from the iron cage of bureaucratic modernity] — understood as Protestant asceticism — was necessary not only because it rendered the phenomenal world fully transparent to scientific inquiry. [It] is logically necessary because it preserves a vantage point outside the 'mechanism' from which the value of the mechanism itself can be accurately and objectively esteemed and condemned" (51). In other words, a critical standpoint is possible from outside the iron cage-is indeed perhaps made possible by an iron cage that exorcised the spirit of its own creation.

Marxian thinkers, such as the critical theorists of the Frankfurt School, lambasted the separation of science from human life and morality, as well as an indifference to nature (Horkheimer and Adorno 2002; Marcuse 1964). There is something of a religion in this, at least in the sense that Horkheimer referred to religion as, "The not-yetstrangled impulse that insists that reality should be otherwise, that the spell will be broken and turn toward the right direction. Where life points this way in every gesture, there is religion" (quoted in Neiman 2002:306).

But the term religion can make us moderns queasy. It cries out for further explanation. It is a term that, where not decidedly unfashionable, has been relegated to cliché. Instructively, the American pragmatist Dewey (2013) distinguishes between a religion which "always signifies some special body of beliefs and practices having some kind of institutional organization, loose or tight" with "the adjective 'religious" which "denotes attitudes that may be taken toward every object and every proposed end or ideal" (9). It may arguably be the case that in the context of the U.S., as is the case in much of Western civilization, that the prevalence of having a religion in the Deweyan sense has declined in recent decades, and may continue to do so in the future (see, for example, Norris and Inglehart 2011). To be religious on the other hand neither requires nor presupposes an institutional affiliation nor necessitates a "fixed" doctrine. It may not be possible to directly quantify what it means to be religious given the plurality of possible incarnations of being religious, of having faith. 
The lesson I glean from Hamlet is not a sermon warning of the dangers of a secularizing modernity, but an inculcation of something most would probably be more comfortable referring to as faith. Faith cannot only coexist with the modern but help us consider new ways to live in this newfound ambivalence. This is not necessarily the faith of organized religion, and is not the atavistic longing for the return to an imagined pre-ambivalent prehaunting - even if the latter were desirable (and I contend that it is not) we can no more do this than Hamlet can undo the tragedy that unfolds around him. Nor can the lesson be a simple choice of "believing in" or "not believing in" ghosts — whatever that may ultimately mean — let alone knowing with certainty in advance what the consequences will be for delaying, or for acting.

Similarly, to have faith does not necessarily mean doing so in the context of an organization, tradition, institution-religious or otherwise (though it does not a priori circumscribe such, either). It involves a willingness to stand outside the iron cage, to recognize in all its poignancy, as Weber did, that, "after Nietzsche one could no longer look to science to free us from political decisions or give meaning to life" (Antonio 2015). The Providence of Hamlet at the end of the play may be read, alternatively, not merely as a residue of predestination but of a practical commitment - he has examined the evidence, but more importantly, he has seen the suffering that ensued with delay. It was time to act. Just as Hamlet could have acted differently, we could act differently, still; we have come of age in ambivalence, haunted by a past. Reliable information, noble intention, and the will to act do not guarantee avoidance of tragedy. But Nietzschean-Weberian vantage points outside the iron cage-outside the machine-hold forth promise for the re-development, and re-envisioning, of the machine. Hamlet's haunting, and transition, offers some glimpse of such a vantage. It may be that alternative ontological—and hauntological—visions of the relationship between humanity and nature, as well as between morality and rationality, and between time and selves, can be conceived by taking heed of the spirit that has fled the iron cage, the ghost that exhorts we denizens of (post)(post) modernity to set right the time while_-by_-finding something akin to faith.

\section{Endnotes}

1. While writing this manuscript, I became aware of the vast extent to which Hamlet has been subject to literary interpretation and criticism. For a concise discussion of past "essential criticisms" from schools of thought ranging from Neoclassicism to the New Historicism and Poststructuralism, see Huw Daniel Griffiths (2005). Levinas' invitation, a starting-point for future critiques, appears in this volume on p. 163. Levinas' work on "confronting the other" as an act at once ethical and political is discussed at length in Ethics and Infinity: Conversations with Philippe Nemo and Ethics and Infinity.

2. Though my analysis is ultimately more Weberian and Nietzschean, the work of connecting the act of haunting and the guise of the specter, specifically, of Hamlet's father, to the present political, cultural, and ethical moment, is undertaken at some length by Derrida in the first third of his work, and serves a springboard of sorts in relation both to Levinas' invitation (see footnote 1) and discussion of the phenomena of haunting in relation to the shaping of self and society.

3. An instance of this quotation that is relevant to the work at hand appears in Anthony Matteo's "In Defense of Moral Realism," Telos 106 (Winter 1996), p. 66: Hilary Putnam, in the tradition of American philosophical pragmatism, has been particularly vocal in stressing the need for a broader concept of rationality than the logical positivist and narrowly empiricist approaches, one able to make sense of complex theoretical and practical judgments. "[T]he idea that science (in the sense of exact science) exhausts rationality is seen to be a self-stultifying error. The very activity of arguing about the nature of rationality presupposes a conception of rationality wider than that of laboratory testability. ... [A]ny conception of rationality broad enough to embrace philosophynot to mention linguistics, mentalistic psychology, history, clinical psychology, and so on-must embrace much that is vague, ill-defined, no more capable of being 'scientized' than was the knowledge of our forefathers. The horror of what cannot be 'methodized' is nothing but method fetishism; it is time we got over it." Somewhat ironically, the idea that morality can be reduced to "mere sentiment" arises out of a conception of rationality that is sufficiently narrow as to exclude a great deal of other aspects of human experience. This is not to argue that morality does not have a strong emotional component, as argued as far back as Hume (1978) and corroborated by evidence from moral and political psychology recently compiled in Haidt (2012). Morality, even insofar as it arises out of sentiment, is not therefore beyond rational discourse, raising anew even the possibility of moral realism, the popular argument in philosophical ethics that disagreement across cultures and times regarding moral principles is often overemphasized. Speaking as a pragmatist: 
insofar as morality is not ejected from the realm of rationality, moral principles can be "translated" crossculturally in the way that other forms of intersubjectively verifiable knowledge can.

4. Indeed, the second half of Marcuse's (1964) work, "One-Dimensional Thought," is largely devoted to the critical examination of a species of analytic philosophy popular in the English-speaking world in the midtwentieth century that became involved in sorting out ever-more tedious linguistic puzzles and in so doing became fundamentally divorced from the practical ethical and political questions and engagements that characterized, in particular, classical Greek philosophy. In this regard if not in others, Marcuse's critique of midtwentieth century analytic philosophy is an ally to the philosophical pragmatism that undergirds this analysis.

5. The noumenal-phenomenal distinction comes from Immanuel Kant. With Lough (2006), I detect Kantian notes in Weber, though Weber in his social constructivism did not draw as bright a line between noumena and phenomena, and therefore between value and fact, or between the sublime and the observable. It is worth noting that Nietzsche builds his critique of Enlightenment thought across many of his works upon an extended critique of Kantian thought. The distinction between methodological and metaphysical naturalism is expounded upon by Alters (2005) while "non-overlapping magisteria" is a term devised by Gould (1999). Centrally, talk of ghosts, of haunting, implies philosophical conceptions that delve beyond the reach of scientific inquiry; the critique of metaphysical naturalisms and (onto)logical positivisms foregrounds this work. I am not asking my reader to "believe in ghosts," whatever that means, but to consider the role that these conceptual constructions have played in shaping-and perhaps constraining - the range of ethical and political deliberative possibilities that inhere in the modern self.
6. Hamlet quotes are taken from Modern Folio 1, and listed by act, scene, and lines http://internetshakespeare. uvic.ca/doc/Ham_FM/scene/1.5/\#tln-725

7. Men of knowledge retain their faith in truth for Nietzsche; as for Weber, they retain their passion for their calling, for pursuit of knowledge. In the case of Merton, the scientist's status gives rise to roles in which sociological ambivalence inheres, placing demands on the scientist in terms of conduct that are at odds with the passion and competitive fervor that often characterizes scientific endeavor (see Merton 1970:3264). All three men argue that there is something of the ascetic ethic which arose with the Protestant Reformation embedded in scientific and intellectual pursuits, and each seems to hold some ambivalence toward science, though their respective emphases differ in interesting regards that are beyond the scope of this paper.

8. This is the synthesis of points made by both Nietzsche and Weber in previous sections of this work. Note the use of the German term Beruf which Weber (2011) traces from its root as a originally referring to a Providential calling, and coming to refer to a secularized vocation in the context of the shift toward modernity.

\section{References}

Agger, Ben. 2002. Postponing the Postmodern: Sociological Practices, Selves, and Theories. Lanham: Rowman \& Littlefield Publishers, Inc.

Alters, Brian. 2005. Teaching Biological Evolution in Higher Education: Methodological, Religious, and Non-Religious Issues. Sudbury: Jones and Bartlett Publishers.

Antonio, Robert J. 2015. "Friedrich Nietzsche." in The Blackwell Encyclopedia of Sociology, George Ritzer, ed. Malden, MA: Blackwell Publications.

Belsey, Catherine. 1985. The Subject of Tragedy: Identity and Difference in Renaissance Drama. London: Methuen.
Derrida, Jacques. 1994. Specters of Marx. New York: Routledge.

Dewey, John. 2013. A Common Faith, Second Edition. Introduction by Thomas M. Alexander. New Haven: Yale University Press.

Evans, John H. and Michael S. Evans. 2008. "Religion and Science: Beyond the Epistemological Conflict Narrative." Annual Review of Sociology 34:87-105.

Flatter, Richard. 1949. Hamlet's Father. New Haven: Yale University Press.

Fukuyama, Francis. 1992. The End of History and the Last Man. New York: Avon. 
Giddens, Anthony. 2000. Runaway World: How Globalization is Reshaping our Lives. New York: Routledge.

Gould, Stephen Jay. 1999. Rocks of Ages: Science and Religion in the Fullness of Life. New York: Ballantine.

Griffiths, Huw Daniel. 2005. Shakespeare Hamlet: A Reader's Guide to Essential Criticism. New York: Palgrave Macmillan.

Haidt, Jonathan. 2012. The Righteous Mind: Why Good People are Divided by Politics and Religion. New York: Pantheon Books.

Horkheimer, Max and Theodor W. Adorno. 2002. Dialectic of Enlightenment. Stanford: Stanford University Press.

Hume, David. 1978. A Treatise of Human Nature. New York: Oxford University Press.

Jones, Robert P. 2016. The End of White Christian America. New York: Simon \& Schuster.

Levinas, Emmanuel. 1985. Ethics and Infinity: Conversations with Philippe Nemo. Pittsburg, PA: Duquesne University Press.

Levinas, Emmanuel. 1989. From Time and the Other [19461947]. Translated by Richard A. Cohen in The Levinas Reader, edited by Seán Hand. Oxford: Blackwell.

Lough, Joseph W.H. 2006. Weber and the Persistence of Religion: Social Theory, Capitalism, and the Sublime. New York: Routledge.

Marcuse, Herbert. 1964. One-Dimensional Man. Boston: Beacon Press.

Matteo, Anthony. 1996. "In Defense of Moral Realism.” Telos. 106:64-76.

Merton, Robert K. 1970. Science, Technology, and Society in Seventeenth-Century England. New York: Howard Fertig.
Merton, Robert K. 1976. Sociological Ambivalence and Other Essays. New York: The Free Press.

Modood, Tariq. 2013. Multiculturalism, Second Ed. Malden, MA: Polity Press.

Neiman, Susan. 2002. Evil in Modern Thought: An Alternative History of Philosophy. Princeton: Princeton University Press

Nietzsche, Friedrich. 1967. Genealogy of Morals, translated by Walter Kaufmann and R.J. Hollingdale. New York: Vintage Books.

Norris, Pippa and Ronald Inglehart. 2011. Sacred and Secular: Religion and Politics Worldwide. New York: Cambridge University Press.

Oreskes, Naomi and Erik M. Conway. 2010. Merchants of Doubt: How a Handful of Scientists Obscured the Truth on Everything from Tobacco Smoke to Global Warming. New York: Bloomsbury Press.

Putnam, Hilary. 1995. The Many Faces of Realism. Chicago, IL: Open Court.

Stoll, Mark R. 2015. Inherit the Holy Mountain: Religion and the Rise of American Environmentalism. New York: Oxford University Press.

Szrot, Lukas. 2015. "Defending Moral Realism.” Telos, September 9. Retrieved April 1, 2019 http://www.telospress. com/defending-moral-realism/

Szrot, Lukas. 2019. "The Promise and Pitfalls of Public Sociology." Social Thought and Research 35:9-13 (in print).

Weber, Max. 1946. From Max Weber: Essays in Sociology. Translated by H.H. Gerth and C. Wright Mills. New York: Oxford University Press. 